\title{
An Arginine to Histidine Mutation in Codon 311 of the C-erbA $\beta$ Gene Results in a Mutant Thyroid Hormone Receptor That Does Not Mediate a Dominant Negative Phenotype
}

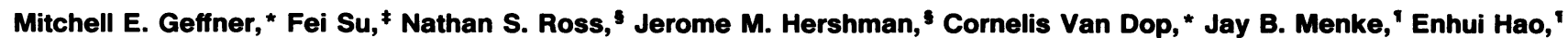 \\ Richard K. Stanzak, " Twilla Eaton, "Herbert H. Samuels, $\neq \|$ and Stephen J. Usala" \\ * Department of Pediatrics, UCLA Medical Center, Los Angeles, California 90024; ${ }^{\S}$ Department of Medicine, UCLA Medical Center and \\ the West Los Angeles Veterans Administration Medical Center, Los Angeles, California 90073; ${ }^{\ddagger}$ Department of Pharmacology and \\ "Division of Molecular Endocrinology, Department of Medicine, New York University Medical Center, New York 10016; and \\ 'Department of Medicine, East Carolina University School of Medicine, Greenville, North Carolina 27858
}

\begin{abstract}
We have examined the c-erbA $\beta$ thyroid hormone receptor gene in a kindred, G.H., with a member, patient G.H., who had a severe form of selective pituitary resistance to thyroid hormones (PRTH). This patient manifested inappropriately normal thyrotropin-stimulating hormone, markedly elevated serum free thyroxine $\left(T_{4}\right)$ and total triiodothyronine $\left(T_{3}\right)$, and clinical hyperthyroidism. The complete c-erbA $\beta 1$ coding sequence was examined by a combination of genomic and cDNA cloning for patient G.H. and her unaffected father. A single mutation, a guanine to adenine transition at nucleotide 1,232 , was found in one allele of both these members, altering codon 311 from arginine to histidine. In addition, a half-sister of patient G.H. also harbored this mutant allele and, like the father, was clinically normal. The G.H. receptor, synthesized with reticulocyte lysate, had significantly defective $T_{3}$-binding activity with a $K_{\mathrm{a}}$ of $\sim 5 \times 10^{8} \mathrm{M}^{-1}$. RNA phenotyping using leukocytes and fibroblasts demonstrated an equal level of expression of wild-type and mutant alleles in patient G.H. and her unaffected father. Finally, the G.H. receptor had no detectable dominant negative activity in a transfection assay. Thus, in contrast to the many other $\beta$-receptor mutants responsible for the generalized form of thyroid hormone resistance, the G.H. receptor appeared unable to antagonize normal receptor function. These results suggest that the arginine at codon 311 in $c-e r b A \beta$ is crucial for the structural integrity required for dominant negative function. The ARG-311-HIS mutation may contribute to PRTH in patient G.H. by inactivating a $\beta$-receptor allele, but it cannot be the sole cause of the disease. (J. Clin. Invest. 1993. 91:538-546.) Key words: thyroid hormone receptor • resistance $\cdot$ mutation
\end{abstract}

\section{Introduction}

Generalized resistance to thyroid hormones (GRTH) ${ }^{1}$ is a syndrome characterized by a clinically euthyroid state, elevated

Address reprint requests to Dr. Stephen J. Usala, Department of Medicine, East Carolina University School of Medicine, Greenville, NC 27858-4354.

Received for publication 21 April 1992 and in revised form 12 September 1992.

1. Abbreviations used in this paper: chloramphenicol acetyltransferase GRTH, generalized resistance to thyroid hormones; PCR, polymerase chain reaction; PRTH, pituitary resistance to thyroid hormones; TRAP, thyroid hormone receptor auxiliary proteins; TRE, thyroid

The Journal of Clinical Investigation, Inc.

Volume 91, February 1993, 538-546 levels of free thyroid hormones, and inappropriately normal thyrotropin-stimulating hormone (TSH) (1). The majority of patients with this genetic syndrome have been found to have mutations in one allele of the c-erbA $\beta$ thyroid hormone receptor gene on chromosome $3(2,3)$. These mutations have been located in the thyroid hormone-binding domain $\left(\mathrm{T}_{3}\right.$-binding domain) of the c-erbA $\beta$ receptor ( $\beta$-receptor) and result in mutant proteins with variable $T_{3}$-binding affinity (4-12). Some mutant receptors such as those from kindreds $\mathrm{Mf}$ and $\mathrm{S}$ $(4,7)$ have an undetectable $T_{3}$-binding affinity, whereas other mutant receptors such as those from kindreds CL and WR (8, 11 ) have reduced, but considerable $T_{3}$-binding activity. The vast majority of these mutations lie within the penultimate and final exons of the receptor gene. Transient expression studies using these mutant receptors and thyroid hormone response elements (TREs) in heterologous promoters have demonstrated variable transactivating function that correlated with the $T_{3}$-binding affinities of the mutant receptors $(13,14)$.

The molecular basis of GRTH is a dominant negative function conferred by the $\mathrm{T}_{\mathbf{3}}$-binding domain mutations. These mutant receptors inhibit in some manner thyroid hormone action mediated by wild-type receptor from the remaining $\beta$ receptor allele and from the two c-erbA $\alpha$ receptor (15) alleles on chromosome 17 . The dominant negative activity resulting from the single allele c-erbA $\beta$ mutations can be inferred from kindred G (16-19). The Refetoff patients with GRTH in kindred $\mathrm{G}$ have total absence of functional $\beta$-receptor. However, the obligate heterozygotes with only one normal $\beta$-allele from kindred $\mathrm{G}$ are phenotypically normal (16-19). These genetic data taken together demonstrate that the mutant $\beta$-receptors of GRTH must act by antagonizing wild-type thyroid hormone receptor function and not solely through lack of activity $(18,19)$. Furthermore, a patient from kindred S, the Bercu patient, has been described who is homozygous for a dominant negative $\beta$-mutation $(7,20,21)$. The Bercu patient differs from the Refetoff patients and patients with heterozygous $\beta$-mutations in that he is much more severely resistant to thyroid hormones. The Bercu patient, by way of comparison with the Refetoff patients, demonstrates that a dominant negative $\beta$-receptor can inhibit at least some of the functions in man of the $\alpha$-receptor. Finally, several transfection studies with the human mutant $\beta$-receptors support the notion of dominant negative activity drawn from these genetic data $(13,14,22)$.

Selective pituitary resistance to thyroid hormones (PRTH)

hormone response element; TRE $_{\mathrm{ir}}$, inverted repeat TRE; TSH, thyrotropin-stimulating hormone. 
is a syndrome of clinical hyperthyroidism, with elevated free thyroid hormones, but inappropriately normal serum TSH levels as described by Gershengorn and Weintraub (23). Unlike GRTH, where the syndrome usually segregates with a dominant allele, ${ }^{2}$ the mode of inheritance in PRTH has not been established and the molecular pathology of this variant form of thyroid hormone resistance has not been elucidated.

Our attention was drawn to a kindred G.H. because of an unusual patient (patient G.H.) with markedly elevated free thyroxine $\left(T_{4}\right)$ and $T_{3}$, and overt hyperthyroidism but with inappropriately normal TSH (24). Although patient G.H. satisfied the criteria for PRTH, she differed from previously reported cases in terms of strikingly elevated serum thyroxine $\left(T_{4}\right)$, free $T_{4}$, and $T_{3}$ levels $(25,26)$. In our search for the cause of PRTH in patient G.H., a mutation in the $T_{3}$-binding domain of $c-\operatorname{erbA} \beta$ was identified. Quite unexpectedly, this mutant allele did not confer thyroid hormone resistance to other members of kindred G.H. This lack of dominant negative activity of the G.H. receptor was confirmed in a transfection assay. We report here a mutant $c-e r b A \beta$ that has defective $T_{3}$-binding affinity but does not result in dominant negative activity in humans.

\section{Methods}

Phenotyping. Informed consent was obtained from all members and/ or their parents of kindred G.H. TSH, free $\mathrm{T}_{4}, \mathrm{~T}_{4}, \mathrm{~T}_{3}, \alpha$-subunit, sex hormone-binding globulin, and cholesterol were assayed in the clinical laboratories of the UCLA Medical Center, the West Los Angeles Veterans Administration Medical Center, or Endocrine Sciences (Calabasas Hills, CA). Pulse, weight, and height were obtained during physical examination. Patient G.H. with severe PRTH has been followed serially and treated at the Pediatric Endocrinology Clinic, UCLA School of Medicine, and has been studied in the Clinical Research Center of the West Los Angeles Department of Veterans Administration Medical Center (24).

DNA and RNA preparation. Leukocyte DNA was prepared from subjects as previously described (27). Leukocyte RNA was obtained from the father (member 1, see Fig. 1). Blood obtained by phlebotomy was immediately centrifuged; the buffy cell layer was removed and placed in a $15-\mathrm{ml}$ solution containing guanidinium isothiocyanate (5). This solution was frozen at $-80^{\circ} \mathrm{C}$ until total RNA was recovered by centrifugation through cesium chloride (5). Skin biopsies were performed on patient G.H. and her father. Primary fibroblast cell lines were established from both patients and total RNA was isolated by lysis in guanidinium isothiocyanate and centrifugation through cesium chloride (5).

Genomic cloning and sequencing. The genomic sequences of c-er$b \mathrm{~A} \beta$ in patient G.H. and her father were examined using the same strategy that has been successfully applied in kindreds $\mathrm{D}, \mathrm{S}$, and $\mathrm{CL}$ $(6-8,28)$. Multiple clones of exons 5-10 were sequenced using amplimers that have been previously published ${ }^{3}$ and the polymerase chain reaction (PCR) $(3,8)$. The majority of exon 4 at the $\mathrm{NH}_{2}$ terminus was cloned (codons 7-86) with amplimers 5'-GGGGATCCATCTGGTTACCTTTACATTT-3' and 5'-GGGAATTCAACCCTTTAGAAA

2. The Refetoff mutation is an exception to this rule. GRTH was inherited recessively in kindred $G(16)$.

3. This exon numbering is according to Cugini et al. (8). Sakurai et al. (29) have assigned a different nomenclature; addition of -2 to the exon numbers here translates to their coordinate system. Also, Sakurai et al. have noted a correction in the $\mathrm{NH}_{2}$ - terminus of the originally published c-erbA $\beta$ sequence (30), which predicts an additional five amino acid residues. The codon coordinates used here can be converted to the Sakurai et al. coordinates by +5 .
ATGGCCT-3' and PCR conditions of $94^{\circ} \mathrm{C}$ for $1 \mathrm{~min}, 55^{\circ} \mathrm{C}$ for $1 \mathrm{~min}$, and $72^{\circ} \mathrm{C}$ for $2 \mathrm{~min}$.

The following genomic clones of $\mathrm{c}-\operatorname{erbA} \beta$ were sequenced from patient G.H.: exon 5 (codons 90-123, 12 clones), exon 6 (codons 124-173, 11 clones), exon 7 (codons 173-240, 12 clones), exon 8 (codons 241-290, 10 clones), exon 9 (codons 291-377, 17 clones), and exon 10 (codons $377-457,11$ clones). The following genomic clones were sequenced from the father: exon 4 (portion consisting of codons 7-86; 11 clones) and exon 9 ( 6 clones). Also, 6 clones of exons 7 and 10 were partially sequenced. Unless otherwise stated, all PCR amplification conditions that follow were $94^{\circ} \mathrm{C}$ for $1 \mathrm{~min}, 55^{\circ} \mathrm{C}$ for 1 $\min$, and $72^{\circ} \mathrm{C}$ for $2 \mathrm{~min}$.

cDNA cloning and sequencing. A partial cDNA containing the 3'coding portion of c-erbA $\beta 1$ was cloned using leukocyte RNA from the father. An antisense oligomer to the 3 '-untranslated region of $\mathrm{c}-\operatorname{erbA} \beta$ was used for first strand synthesis using avian myeloblastosis virus reverse transcriptase (7) and the resulting cDNA amplified with this antisense oligomer and with oligomer (5'-CAATTACCAGAGTGGTGGATTTTGCCA-3', nucleotides 1,120-1,147). This PCR produced a cDNA containing codons $283-457$, which was gel-purified in NuSieve GTG (FMC Corp., Rockland, ME) for RNA phenotyping purposes (see below).

C-erbA $\beta 1$ cDNAs from patient G.H. and her father were cloned from fibroblast RNA in overlapping $5^{\prime}$ and $3^{\prime}$ portions. The 5'-cDNAs were synthesized using oligomer (5'-GGTCGCCACATGGGCTTCGGTGACAGT-3', nucleotides 981-955) for first strand synthesis and the 3'-cDNAs were synthesized using oligomer (5'-GGAATTATGAGAATGAAT(T)CAGTCAGT-3', nucleotides 1,698-1,672) for first strand synthesis (7). (Nucleotides in parentheses are changes from wild-type sequence to create restriction sites.) The 5'-cDNAs (codons 5'-untranslated-197) were amplified by PCR with amplimers (5'CCTGCGTGGGT(A)CCAAGTTCCACACAT-3', nucleotides 209235) and (5'-CTTGTGCCCGATGGACTTCTGCAGCTC-3', nucleotides 918-892). The 3'-cDNAs (codons 150-448) were amplified by PCR with amplimers ( 5 '-AAATATGAAGGAAAATGTGTCATAGAC-3', nucleotides 721-747) and (5'-CTAATCCTCGAA(T)(T)CTTCCAAGAACAA-3', nucleotides 1,671-1,645). Control reactions without added RNA or DNA were always run simultaneously to verify lack of contaminants in reagents. Aliquots of the 3 '-cDNA polymerase chain reactions were used in RNA phenotyping (below). Six clones of the BamHI-PstI portion of the 5'-cDNAs (nucleotides 263-895, codons 5'-untranslated-197) of both patient G.H. and her father were sequenced. Two clones (mutant and wild-type) of the PstI-EcoRI portion of the 3'-cDNAs (nucleotides 895-1,657, codons 199-448) of both patient G.H. and her father were sequenced.

Screening for the G.H. mutation. Genomic specimens were screened for the presence of the A-1232 base substitution that eliminated an Hhal restriction site by amplifying a segment bounded by amplimers (5'-AAGACCAGATCATCCTCCTCAAAGGC-3', nucleotides $1,181-1,206)$ and (5'-TCTCACTTTCTGGGTCATAG(T)GCACA-3', nucleotides 1,265-1,239).The second amplimer contained a $C$ to $T$ (nucleotide 1,244), which eliminated an Hhal site that would have confounded the subsequent analysis. The PCR products were extracted with phenol/chloroform, precipitated with ethanol, and digested with $\mathrm{Hhal}$. The digestion products were analyzed on 3 to $4 \%$, 3:1 NuSieve GTG gels. The mutant allele generated an 84-bp fragment that was refractory to Hhal digestion whereas the wild-type allele generated 54-bp and 32-bp bands on Hhal digestion. 48 random individuals ( 96 random alleles) were screened using a panel of DNAs previously published (5-8).

$R N A$ phenotyping. Leukocyte c-erbA $\beta 1$ cDNA (codons 283-457) from the father was gel purified and amplified as described for screening the G.H. mutation. The products were extracted with phenol/ chloroform, precipitated with ethanol, and then submitted to HhaI digestion and gel electrophoresis.

Alternatively, $1-\mu l$ aliquots of the fibroblast cDNA (codons 150 448) for patient G.H. and her father were directly amplified with the screening amplimers for only 15 cycles under the following conditions: 
$94^{\circ} \mathrm{C}, 1 \mathrm{~min} ; 55^{\circ} \mathrm{C}, 30 \mathrm{~s} ; 72^{\circ} \mathrm{C}, 30 \mathrm{~s}$. The amplified products were phenol/chloroform extracted, ethanol precipitated, and then submitted to Hhal digestion and gel electrophoresis.

Construction of the G.H. receptor CDNA and T3-binding studies. A splicing overlap extension method was used to introduce the A-1232 base substitution into the wild-type human placental c-erbA $\beta$ cDNA (peA101) (30) as has been previously detailed $(7,8)$. The portion of the recombinant CDNA, synthesized via PCR, was checked by sequencing to rule out an unintended mutation.

The G.H. receptor and wild-type human $\beta$-receptor were synthesized with reticulocyte lysate using the reticulocyte lysate L$\left[{ }^{35} \mathrm{~S}\right]$ methionine kit (Dupont-New England Nuclear; Wilmington, $\mathrm{DE}),(7,8)$. The $\mathrm{T}_{3}$-binding affinity measurements were done by saturation analysis with $\left[{ }^{125} \mathrm{I}\right] \mathrm{T}_{3}$ and a nitrocellulose filter binding assay $(7,8)$.

Transient transfection analysis of wild-type and mutant human c-er$b A \beta c D N A s$. The assay for transactivation and dominant negative activity of mutant forms of c-erbA has been previously detailed (31). Briefly, the reporter plasmid MTV-TRE $\mathrm{ir}_{\mathrm{ir}}$-CAT (CAT is chloramphenicol acetyltransferase) contains one copy of an inverted repeat (palindromic) thyroid hormone-responsive element $\left(T_{R E}\right.$ ir (AGGTCATGACCT) (31) cloned upstream of a mouse mammary tumor viral LTR-CAT vector lacking glucocorticoid response elements (32). To construct the plasmid vector expressing wild-type human c-erbA $\beta 1$, a fragment encompassing the entire coding region of $c-e r b \mathrm{~A} \beta 1$ in the plasmid pheA4/12 (30) was cleaved with Hinf I. The c-erbA $\beta 1$ sequence (29) predicts that the 5 ' Hinf I cleavage site would remove the first ATG in the open reading frame and the $3^{\prime}$ site would cleave downstream of the stop codon. This fragment was blunt-end ligated into a blunt-ended pEXPRESS vector (33) which had been digested with NcoI and Xhol to remove a rat c-erbA sequence. The blunt-ended Ncol site, when fused to the blunt-ended Hinf I fragment, regenerates the ATG of the open reading frame to form pEXPRESS-wild-type (WT). The StyI-BglII fragment from peA101-G.H. (containing the G.H. mutation) was inserted into the corresponding position in the pEXPRESS-wild-type. The derived pEXPRESS-G.H. vector was verified by restriction enzyme digestions and with DNA sequencing. Translation of in vitro RNA transcripts of pEXPRESS-G.H. in rabbit reticulocyte lysates resulted in the expression of a $\left[{ }^{35} \mathrm{~S}\right]$ methioninelabeled protein of the predicted size. A pEXPRESS vector expressing the kindred $S$ mutation was also constructed using the Styl-Bgl II fragment of the kindred S human c-erbA $\beta$ cDNA in peA101-S. HeLa cells were transfected by electroporation with $5 \mu \mathrm{g}$ of $\mathrm{MTV}^{-T R E_{\mathrm{ir}}}-\mathrm{CAT}$ and with either pEXPRESS-WT, pEXPRESS-G.H., or pEXPRESS-S alone or in various combinations (see Fig. 6). After transfection, cells were incubated for $40 \mathrm{~h}$ without hormone or with $5 \mathrm{nM}$ or $100 \mathrm{nM} \mathrm{T}_{3}$. CAT activity was quantitated using a thin-layer chromatography assay (34). The amount of cell protein assayed and the incubation time were adjusted to yield $\geq 0.5-1.0 \%$ and $\leq 30 \%$ acetylation of $\left[{ }^{14} \mathrm{C}\right]$ chloramphenicol ( total $250,000 \mathrm{cpm}$ ). The fold stimulation represents the ratio of CAT activity in cells incubated with $\mathrm{T}_{3}$ to that in control cells incubated without ligand. The data are shown as the range of duplicate samples from experiments performed on the same day. Variation among duplicated flasks was $<10 \%$.

\section{Results}

Phenotype of kindred G.H. Patient G.H. is a black female who presented at age $12 \mathrm{yr}$ with symptoms and signs of severe hyperthyroidism. Her clinical presentation and course have been detailed elsewhere (24). At presentation, her serum TSH was normal at $5.1 \mu \mathrm{U} / \mathrm{ml}$, but the total $\mathrm{T}_{4}$ was $38.7 \mu \mathrm{g} / \mathrm{dl}$ (normals, $5-13 \mu \mathrm{g} / \mathrm{dl}$ ), and the free $\mathrm{T}_{4}$ index was 58.5 (normals, 5-13). Graves' disease and pituitary tumor were excluded as causes of her hyperthyroidism (24). Her serum $T_{4}$ and $T_{3}$ have remained in the hyperthyroid range since diagnosis, when off of therapy (Table I).
Table I. TSH and Thyroid Hormone Levels in Kindred G.H.

\begin{tabular}{lcccc}
\hline \multicolumn{1}{c}{ Patient } & Age & TSH & Free $\mathrm{T}_{4}$ & $\mathrm{~T}_{3}$ \\
\hline \multirow{4}{*}{${ }^{2}$} & $y r$ & $\mu U / m l$ & $n g / d l$ & $n g / d l$ \\
{$[\mathrm{G}-\mathrm{H}]^{*}$} & $17^{2 / 12}$ & 3.7 & 6.0 & 664 \\
{$[1]$} & 39 & 0.88 & 1.43 & 150 \\
2 & 37 & 0.95 & 0.88 & 133 \\
{$[3]$} & $16^{4} / 12$ & 0.59 & 1.85 & 181 \\
$4^{\ddagger}$ & $23 / 12$ & 1.50 & 1.13 & $224^{\ddagger}$ \\
Normal ranges & & $0.40-4.0$ & $0.71-1.85$ & $80-200$ \\
& & & &
\end{tabular}

* At age $12 \mathrm{yr}$ and $2 \mathrm{mo}$, TSH $=5.1 \mu \mathrm{U} / \mathrm{ml}(0.32-5.0), \mathrm{T}_{4}=38.7$ $\mu \mathrm{g} / \mathrm{dl}(5-13)$, free thyroxine index $=58.5(5-13), \mathrm{T}_{3}=750 \mathrm{ng} / \mathrm{dl}$ (80-200); levels for patient G.H. previously reported in reference 24 . Brackets denote members with ARG-311-HIS mutation in the c-erbA $\beta$ gene. ${ }^{\ddagger}$ Normal range for age, $95-250 \mathrm{ng} / \mathrm{dl}$.

At the time of diagnosis, the patient's bone age was advanced, consistent with the diagnosis of PRTH (bone age of 14 $\mathrm{yr}$, chronologic age of $12 \mathrm{yr}$ ) (24). The patient's height and weight have remained within normal ranges for her age. The serum cholesterol of patient G.H. was below the normal range (24), and her serum sex hormone-binding globulin was $146 \%$ above the mean of the other female members of kindred G.H., consistent with hepatic hyperthyroidism. In contrast to patient G.H., her father and mother (members 1 and 2, Fig. 1), halfsister (member 3, Fig. 1), and half-brother (member 4, Fig. 1) had no history of thyroid disease and had normal TSH and thyroid hormone levels ( Table I). They were clinically euthyroid on examination (Table II).

$A$ mutant c-erbA $\beta$ allele in patient G.H. and her unaffected father. Because of the severe PRTH of patient G.H., genomic DNA was first prepared from her leukocytes and the c-erbA $\beta$ gene was sequenced using a previously described strategy $(7,8$, 28). Multiple clones of exons 5-10 (codons 90-457) from patient G.H. were sequenced, and a single authentic base substitution at nucleotide 1,232 in exon 9, a guanine to adenine, was found in 11 out of 17 independent clones (Fig. 2). Surprisingly, two of six clones of exon 9 from the patient's unaffected father also contained the A-1232 base substitution. To completely evaluate the sequence of the $\beta 1$-receptors, 5 '- and 3 'cDNAs of c-erbA $\beta 1$ (codons 5'-untranslated-197 and 150448 , respectively) from fibroblasts of patient G.H. and her father were also cloned. cDNA segments consisting of codons 5'-untranslated-197 from the 5' clones and codons 199-448

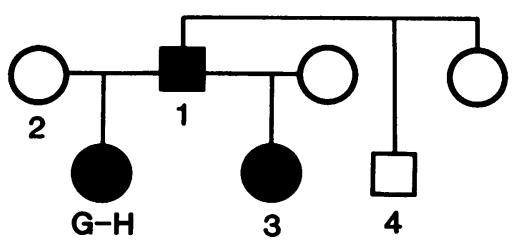

Figure 1. Pedigree of kindred G.H. Members, patient G.H., 3, and 4 have different mothers unrelated to the father, member 1. Members 1,3 , and patient G.H. harbor one mutant $\mathrm{c}$ $\operatorname{erbA} \beta$ allele (see Fig. 3) and are shown by darkened symbols. Members 2 and 4 do not have the mutation. Members 1-4 all had normal levels of serum TSH, free $T_{4}$, and $T_{3}$ and were clinically euthyroid. Patient G.H. had markedly elevated serum free $T_{4}, T_{3}$, and inappropriately normal TSH and was clinically hyperthyroid (Table I). Circles, females; squares, males. 
Table II. Clinical Parameters of Thyroid Hormone Action for Kindred G.H.

\begin{tabular}{|c|c|c|c|c|c|c|c|c|}
\hline \multirow[b]{2}{*}{ Member* } & \multirow[b]{2}{*}{ Age } & \multicolumn{2}{|c|}{ Bone } & \multirow{2}{*}{$\frac{\text { Heart }}{\text { Pulse rate }}$} & \multicolumn{2}{|c|}{ Liver ${ }^{*}$} & \multicolumn{2}{|c|}{ Metabolism } \\
\hline & & Height & Percentile & & SHBG & Cholesterol & Weight & Percentile \\
\hline & $y r$ & $\mathrm{~cm}$ & & per min & $\mu g / d l$ & $m g / d l$ & $k g$ & \\
\hline G.H. & 12 & $157.7^{\S}$ & $75-90$ & 118 & $1.9^{\prime}$ & $146^{\prime}$ & 36.0 & 25 \\
\hline [1] & 39 & 170.8 & $10-25$ & 72 & 0.5 & 204 & 60.5 & $10-25$ \\
\hline 2 & 37 & 160 & 25 & 84 & 1.4 & 299 & 59.1 & $50-75$ \\
\hline [3] & 16.33 & 164.8 & $\sim 90$ & 72 & 1.2 & 179 & 53.6 & $25-50$ \\
\hline 4 & 2.25 & 91 & $\sim 75$ & 104 & 5.4 & 219 & 15.9 & 95 \\
\hline
\end{tabular}

Most clinical data for patient G.H. reported in reference $24 .{ }^{*}$ G.H., 1, and 3 harbor mutation in c-erbA $\beta$ (see Fig. 3). ${ }^{\ddagger}$ SHBG, sex hormone-binding globulin (normals: adult males, 0.5-1.5; adult females, 1.0-3.0; prepubertal children 1.8-5.5 $\mu \mathrm{g} / \mathrm{dl}$ ). Cholesterol normal range is $150-200 \mathrm{mg} / \mathrm{dl}$. ${ }^{\$}$ Bone age of G.H. was $14 \mathrm{yr}$ at chronologic age $12 \mathrm{yr}$. 'SHBG and cholesterol when patient was adult, age $17.25 \mathrm{yr}$.

from the 3 ' clones were sequenced. The only base substitution found in the cDNAs of both patient G.H. and her father was A-1232; cDNAs with the wild-type sequence, G-1232, were
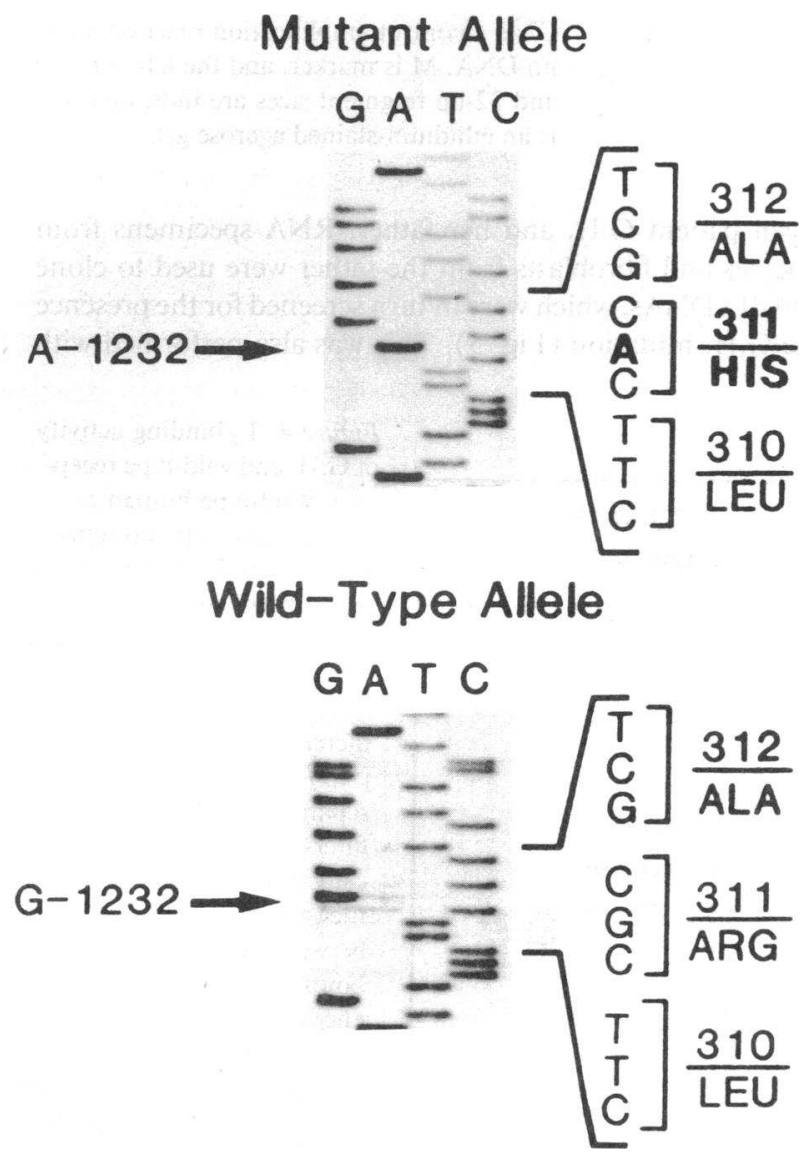

Figure 2. Sequences of mutant and wild-type c-erbA $\beta$ alleles from patient G.H. Multiple clones of exons 5-10 (codons 90-456) from patient G.H. were sequenced and a single base substitution, guanine to adenine, at nucleotide 1,232 was found. This altered an arginine residue at codon 311 to histidine. Also, cDNAs encompassing the cerbAB1 coding sequence of codons 1-448 (30), cloned from G.H. fibroblasts, showed only the A-1232 mutation or wild-type sequence. Genomic and cDNA sequencing of the father of patient G.H., unaffected member 1 (Fig. 1), also revealed only the A-1232 substitution in one allele. also isolated from patient G.H. and her father. In the father, codon 198 and the last 27 coding nucleotides that were not sequenced from the cDNA cloning were also examined by genomic sequencing; multiple clones of exons 7 and 10 were normal. In addition, the majority of the $\mathrm{NH}_{2}$ terminus of genomic $c-e r b \mathrm{~A} \beta 1$ (codons 7-86) which was wild-type was examined in the father. Thus, the entire coding region of $c-e r b A \beta 1$ in patient G.H. and her unaffected father was covered by genomic or cDNA sequencing and, in addition, there was considerable confirmatory overlap between the genomic and cDNA sequencing. In conclusion, both wild-type sequence and a single base alteration of guanine to adenine at nucleotide 1,232 (i.e., two alleles) were identified in patient G.H. and her normal father. This base substitution changed codon 311 from arginine to histidine in the mutant allele.

Two unaffected members of kindred G.H. are heterozygous with the mutant allele. Blood specimens were also obtained from members 2, 3, and 4 (Fig. 1). The A-1232 base substitution eliminated an $\mathrm{HhaI}$ restriction site and a rapid screening method could, therefore, be used (Fig. 3). This screening method revealed wild-type and A-1232 alleles in patient G.H., the father, and in the unaffected half-sister of patient G.H. The mother of patient G.H. and half-brother did not harbor the A-1232 allele. The half-sister was close to the same age as patient G.H. ( Table I) but had no history, symptoms, or signs of thyroid disease. Furthermore, her serum free $\mathrm{T}_{4}, \mathrm{~T}_{3}$, and TSH were within normal ranges. Finally, 48 random individuals ( 96 random alleles) were screened and all lacked the A-1232 base substitution.

The G.H. receptor has defective $T_{3}$-binding activity and is expressed in the unaffected father and patient G.H. To further characterize the G.H. mutation and better understand the finding of normal family members with this mutation, we recreated a G.H. receptor cDNA, synthesized the receptor using reticulocyte lysate, and measured the $\mathrm{T}_{3}$-binding affinity (Fig. 4 ). In three separate experiments, the $T_{3}$-binding affinity of the mutant receptor was near the level of sensitivity of the filter-binding assay $\left(\sim 5 \times 10^{8} \mathrm{M}^{-1}\right)$. A representative $\mathrm{T}_{3}$-binding study with the in vitro mutant receptor and the human placental $\mathrm{c}-\operatorname{erb\mathrm {A}\beta 1}$ receptor is shown in Fig. 4. The magnitude of $\mathrm{T}_{3}$-binding affinity for the G.H. receptor was much lower compared with many other mutant receptors responsible for GRTH (e.g., CL; DC; and E-D, Q-W; references 8, 13, and 9, respectively). The very defective $T_{3}$-binding activity of the G.H. receptor supported the findings of the genetic analysis 
(A)

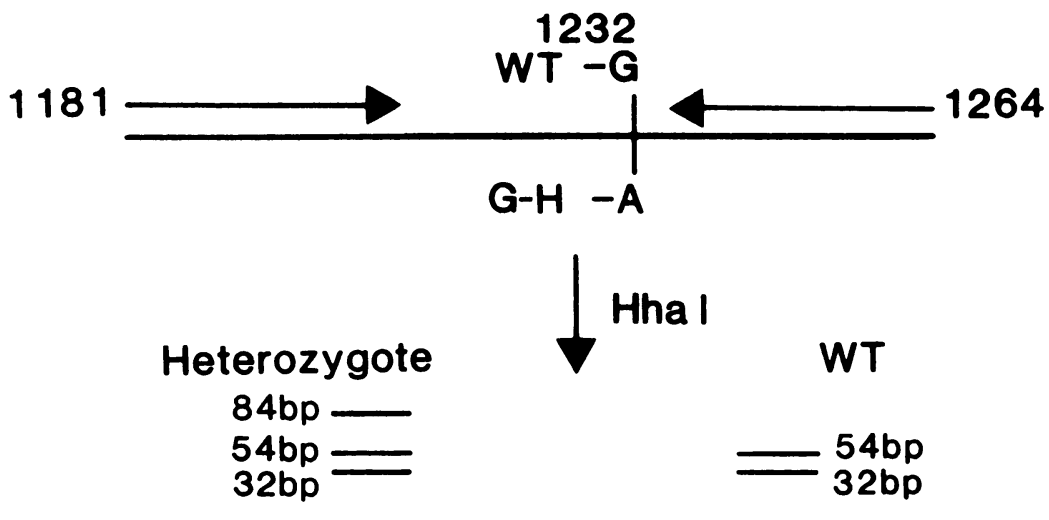

(B)

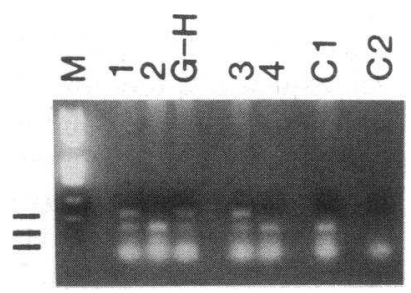

showing that the A-1232 base substitution was a mutation and not a polymorphism.

Given the normal phenotypes of the father and the half-sister, we compared the level of expression of the mutant allele
Figure 3. Screening for the G.H. mutation. The presence of the adenine mutation at nucleotide 1,232 was examined in leukocyte DNA from members of kindred G.H. and in 48 random individuals. $(A)$ Oligomers of nucleotides $1,181-1,206$ and 1,239-1,264 (antisense) were used to amplify a segment containing an HhaI restriction site, which was eliminated by the A-1232 mutation. The wild-type allele generated two fragments of 54- and 32-bp sizes on Hhal digestion of the amplified segment whereas the mutant allele generated an 84bp segment refractory to digestion. The bands shown schematically are from an individual heterozygous for the G.H. mutation (Heterozygote) and from an individual with two normal alleles $(W T)$. (B)

Kindred members 1, G.H., and 3 demonstrated the A-1232 and wild-type sequences whereas members 2 and 4 did not harbor the mutant allele. 48 random individuals did not have the mutation (data not shown). $\mathrm{Cl}$ is a random individual, and $\mathrm{C} 2$ is a control amplification reaction with no DNA. $M$ is marker, and the 84-, 54-, and 32-bp fragment sizes are indicated. $B$ is an ethidium-stained agarose gel.

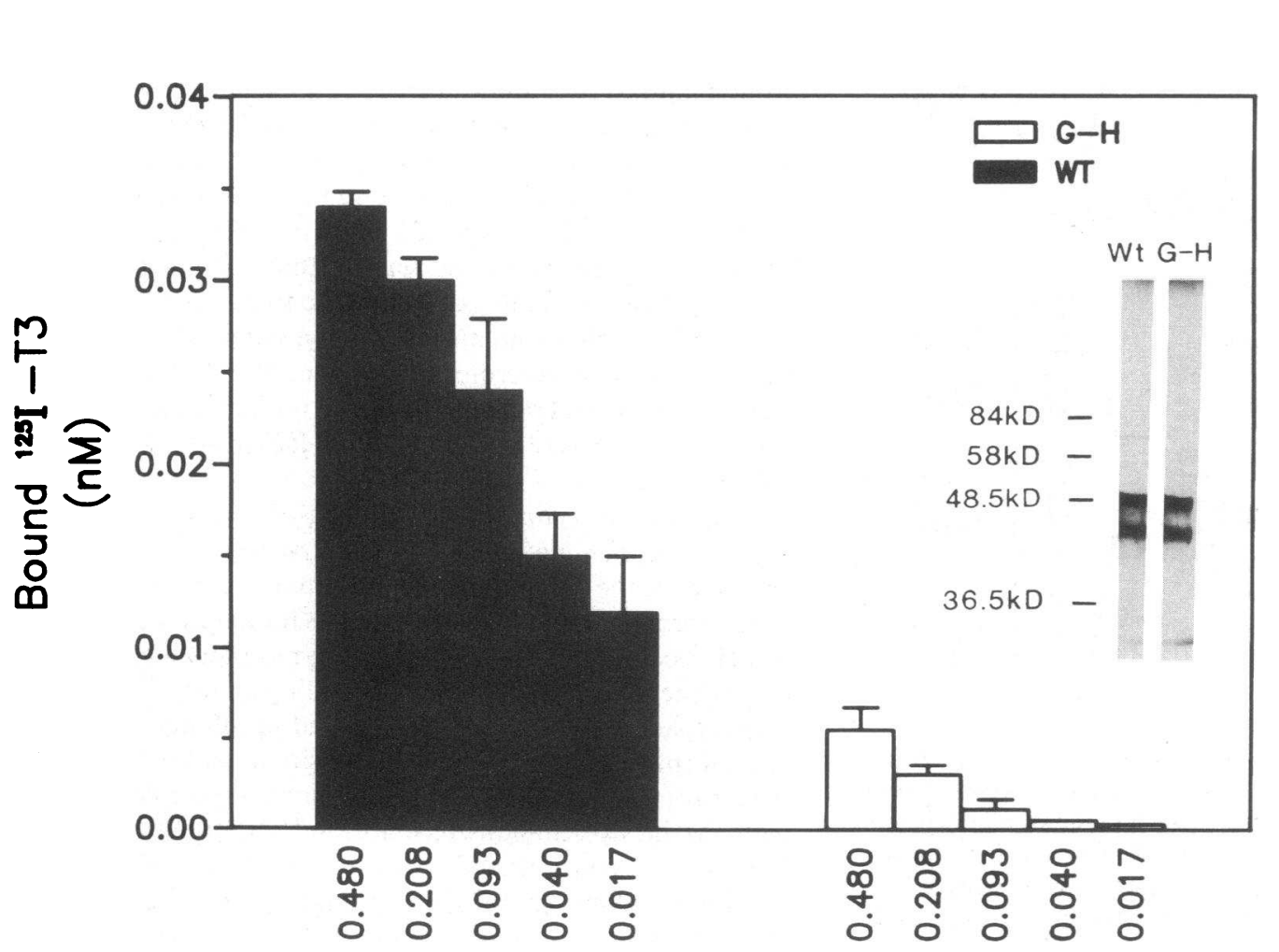

125I-T3 Concentration ( $\mathrm{nM}$ ) between patient G.H. and her father. RNA specimens from leukocytes and fibroblasts from the father were used to clone

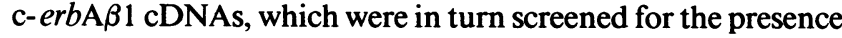
of the G.H. mutation (Fig. 5). This was also performed with

Figure 4. $\mathrm{T}_{3}$-binding activity of G.H. and wild-type receptors. Wild-type human c$\operatorname{erb} \mathrm{A} \beta 1$ and G.H. proteins were synthesized with reticulocyte lysate and used to measure $\mathrm{T}_{3}$-binding activity. Two microliter aliquots of lysate were incubated with increasing concentrations of $\left[{ }^{125} \mathrm{I}\right] \mathrm{T}_{3}$; bound $\left[{ }^{125} \mathrm{I}\right] \mathrm{T}_{3}$ was separated from free by a filter-binding assay. Specifically bound $\left[{ }^{125} \mathrm{I}\right] \mathrm{T}_{3}$ was measured as the difference between the total amount bound and that in the presence of $0.5 \mu \mathrm{M}$ unlabeled $\mathrm{T}_{3}$. The $\mathrm{T}_{3}$-binding affinity of the wild-type receptor in this representative experiment was $2.9 \times 10^{10} \mathrm{M}^{-1}$ whereas the G.H. protein had an affinity of $\sim 7 \times 10^{8} \mathrm{M}^{-1}$. Approximately equal amounts of proteins (TCA-precipitable ${ }^{35} \mathrm{~S}$ ) were used and the

$\left[{ }^{35} \mathrm{~S}\right]$ methionine-labeled proteins were analyzed by SDSPAGE (inset). 

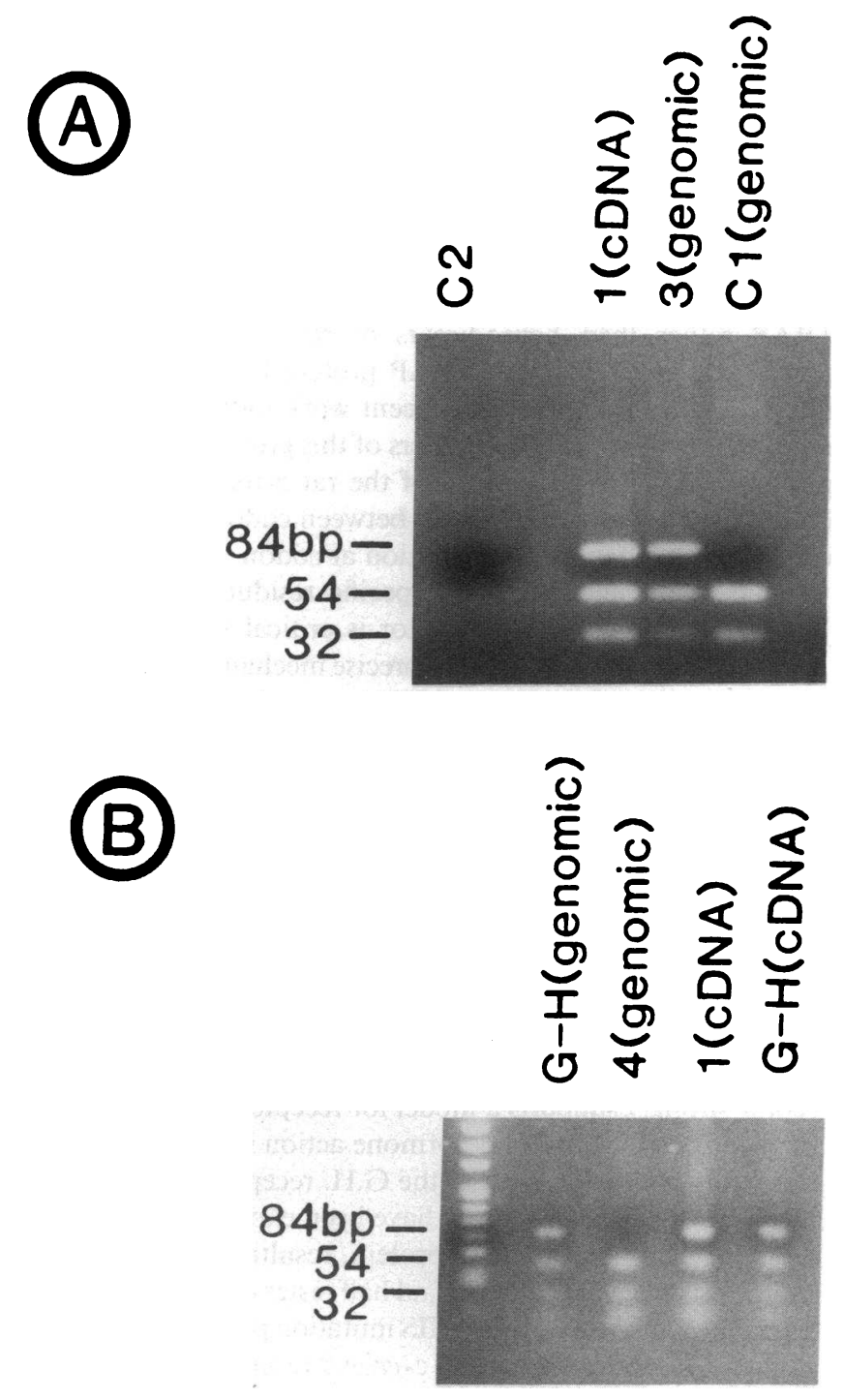

Figure 5. RNA phenotyping: mutant versus wild-type c-erbA $\beta 1$ expression in patient G.H. and in her unaffected father. $(A)$ Leukocyte RNA was prepared from the father, who had a normal phenotype but harbored the G.H. mutation. C-erbA $\beta 1$ cDNA (codons 283-456), synthesized by reverse transcription and PCR amplification, was gel-purified and screened for mutant and wild-type sequences by the method shown in Fig. 3. The 84-bp amplified product that was refractory to Hhal digestion contained the G.H. mutation; the two lower bands ( 54 and $32 \mathrm{bp}$ ) were generated from the population of wild-type cDNA. For comparative purposes, genomic DNA from patient 3 , who had a mutant and a wild-type allele, and from a normal individual, $\mathrm{Cl}$, were similarly screened for the G.H. mutation. C2 was a control amplification reaction without added DNA. (B) Fibroblast RNA was prepared from patient G.H. and her father, and cerbA $\beta 1$ cDNAs (codons 150-448) were cloned by reverse transcription and PCR amplification. 1- $\mu$ l aliquots from these PCR amplifications were further amplified 15 cycles with the screening amplimers in Fig. 3 and the products were subjected to Hhal digestion. The 84-bp band produced from mutant cDNA and the 54- and 32-bp bands produced from wild-type cDNA were seen in patient G.H. and her father. For comparative purposes, genomic DNA from patient G.H. (G.H. genomic) and from her unaffected half-brother with two normal alleles ( 4 genomic) were screened for the G.H. mutation as described in Fig. 3. $A$ and $B$ are taken from ethidium-stained gels. fibroblast RNA from patient G.H. To compare the proportion of mutant versus wild-type cDNA, genomic DNA specimens from wild-type individuals and heterozygous mutant carriers (half-sister or G.H.) were also amplified, screened with HhaI, and run on the same agarose gel (Fig. 5). (The relative intensities on ethidium-staining of the mutant [84-bp] band vs. wildtype [54-bp, 32-bp] bands from the heterozygous, genomic specimens correspond to products produced from a 1:1 proportion of mutant vs. wild-type DNA template.) The results shown in Fig. 5 indicate that the relative abundance of mutant to wild-type fibroblast cDNA, and therefore, mRNA, for both the father and patient G.H. was approximately $1: 1$. The father also showed equal abundance of mutant and wild-type mRNA in leukocytes. We infer from these data that the normal phenotypes of the father and half-sister cannot be explained by lack of expression of the G.H. allele but must result from a lack of dominant negative function of the mutant receptor.

The mutant G.H. receptor minimally transactivates but exhibits no dominant negative activity in transient transfection studies. The remarkable in vivo data were substantiated by transfection in HeLa cells, which has been used to assay transactivation and dominant negative properties of artificial and natural c-erbA $\beta$ mutants $(13,31)$. The ability of G.H. receptor to induce MTV-TRE $\mathrm{ir}_{\mathrm{ir}}-\mathrm{CAT}$ was measured versus that of the wild-type c-erbA $\beta 1$ receptor (Fig. 6). At $100 \mathrm{nM} \mathrm{T}_{3}$, stimulation of CAT activity by the G.H. receptor in HeLa cells transfected with 2 or $20 \mu \mathrm{g}$ of pEXPRESS-G.H. was only two- to threefold. In contrast, stimulation in cells transfected with $2 \mu \mathrm{g}$ of the wild-type human c-erbA $\beta$ vector was $\sim 60$-fold at $5 \mathrm{nM}$ $\mathrm{T}_{3}$ and 100 -fold with $100 \mathrm{nM} \mathrm{T}_{3}$. The ability of the G.H. receptor to block wild-type receptor function was studied along with a vector expressing the mutant kindred $S$ receptor. The kindred $\mathrm{S}$ cDNA was cloned from a family with generalized resistance to thyroid hormone (7) and can mediate a potent dominant negative effect (13). The kindred $S$ receptor, which has virtually no affinity for $T_{3}$, does not transactivate the $T R E_{i r}$ reporter gene and markedly inhibits wild-type receptor function in HeLa cells (Fig. 6) (13). The G.H. receptor did not inhibit $T_{3}$ stimulation of wild-type receptor even at a G.H./wild-type plasmid mass of 20:2 $\mu \mathrm{g}$. In contrast, $10 \mu \mathrm{g}$ of the kindred $\mathrm{S}$ expression vector almost completely inhibited $T_{3}$ stimulation in cells cotransfected with $2 \mu \mathrm{g}$ of the wild-type receptor expression vector. Thus, there is excellent correlation between the in vivo characteristics of the G.H. mutation determined by the genetic analysis and the properties as assayed by transfection.

\section{Discussion}

All human mutations identified to date in the c-erbA $\beta$ gene have resulted in the generalized form of resistance to thyroid hormones. Over 25 different point mutations have been reported (4-12), and all lie within exon 9 or 10 with the exception of one identified in exon 7 (35). A single case of a double mutation in exon 9 and exon 10 has also been found (10). The mutations that have been characterized all variably affect $T_{3}$-binding affinity (twofold reduction to complete $T_{3}$-binding inactivity) and have different potencies as dominant negative proteins on thyroid hormone-regulated reporter genes in transient transfection systems $(4,7-9,11,13,14,22)$. Most importantly, the genetic analysis of GRTH is entirely consistent with a dominant negative mechanism where a mutant c-erbA $\beta$ al- 


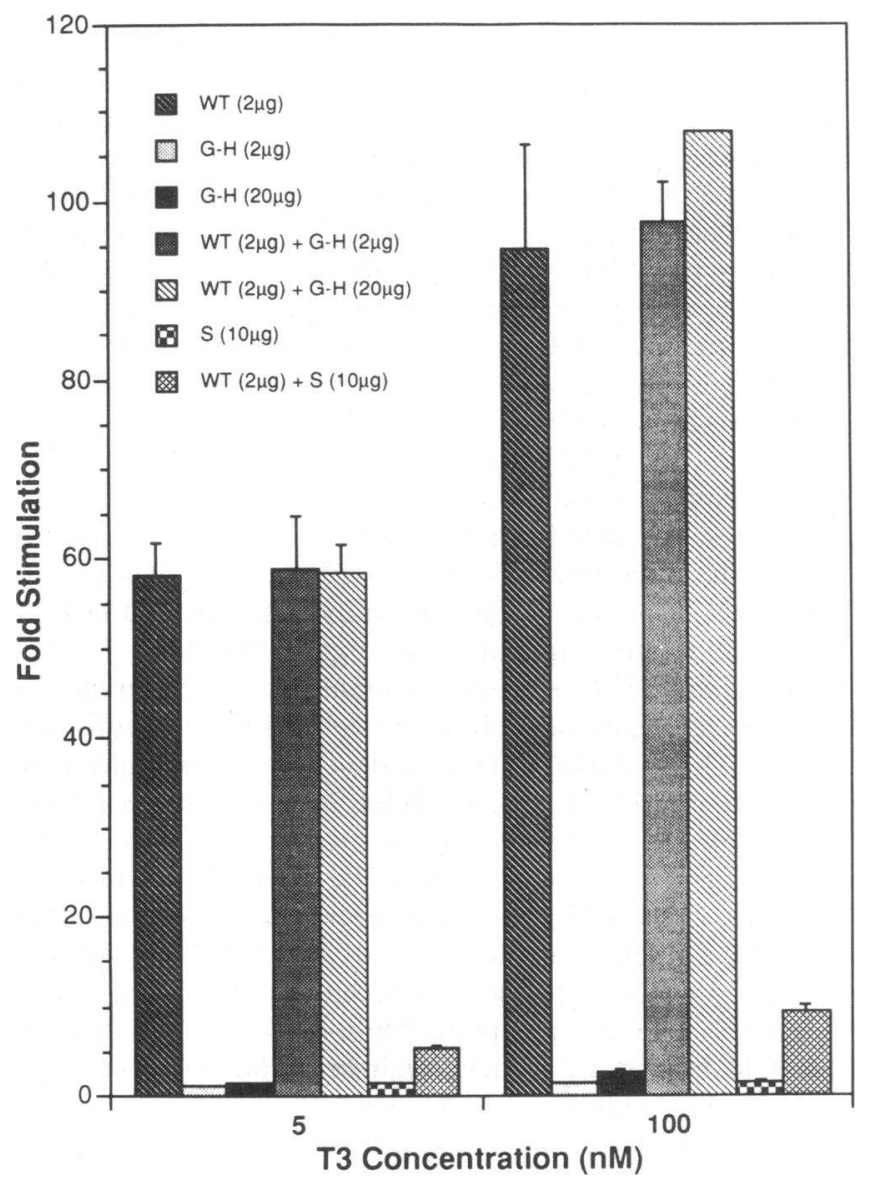

Figure 6. Transactivation and dominant negative properties of the mutant G.H. receptor. pEXPRESS vectors (regulated by the Rous sarcoma virus LTR) expressing either the human c-erbA $\beta 1$ wild-type $(W T)$ or the mutant G.H. or S receptors were transfected into HeLa cells as indicated. All transfections contained $5 \mu \mathrm{g}$ of the MTVTRE $_{i r}-C A T$ reporter gene $\left(T_{R E}=\right.$ AGGTCA TGACCT $)$. Duplicate flasks were incubated for $40 \mathrm{~h}$ without hormone or with either low ( $5 \mathrm{nM}$ ) or high (100 $\mathrm{nM}) \mathrm{T}_{3}$ concentrations. Results of CAT assays are expressed as fold stimulation calculated as the ratio of $\mathrm{T}_{3}$-stimulated activity divided by the basal activity.

lele universally segregates with the affected phenotype (27, 28 ). The only exceptions to this rule are the Refetoff patients of kindred $\mathrm{G}$, where homozygosity for a major $\beta$-gene deletion resulted in GRTH $(18,19)$. Significantly, the Refetoff heterozygotes of kindred $G$ were phenotypically normal. The central result of our study with kindred G.H. is that a point mutation in proximity to a "hot spot" of exon 9 (9) did not segregate as a dominant allele with thyroid hormone resistance. The demonstration that two members with the mutation had normal thyroid function tests and were clinically euthyroid indicates that the ARG-311-HIS mutation does not result in dominant negative function. Given its significantly defective $\mathrm{T}_{3}$-binding affinity, the G.H. receptor would be severely compromised in its transactivation activity and in its ability to mediate thyroid hormone action. The transfection studies with the G.H. receptor support the inference of relative lack of transactivation and dominant negative functions. The G.H. allele, therefore, appears to be a "null allele," and the phenotypes of the father and half-sister are consistent with that of the Refetoff heterozygotes.
The fact that ARG-311-HIS did not by itself lead to dominant negative activity uncovers a functional complexity to the $\mathrm{T}_{3}$-binding domain of c-erbA $\beta$ in vivo. This functional complexity has already been partially elucidated by recent transfection and DNA-binding studies that indicate the existence of thyroid hormone receptor auxiliary proteins (TRAP) that heterodimerize with the $\beta$ - and $\alpha$-receptors and potentiate DNA binding and possibly transactivation $(31,36-44)$. These studies imply that heterodimers of $\beta$-receptor TRAP or $\alpha$-receptor TRAP rather than homodimers of receptors transactivate genes. The identity of the TRAP protein or proteins is still under investigation, but very recent work indicates that retinoid $X$ receptors may be members of this group (45-48). One portion of the TRAP domain of the rat $\beta$-receptor has been determined to lie approximately between codons 280 and 300 $(38,40)$, very close to the mutation at codon 311 .

This study suggests that a specific residue in the ligandbinding domain of the $\beta$-receptor is critical for a dominant negative function. Although the precise mechanism of the dominant negative effect of the GRTH mutations has not been elucidated, it appears that the mutant receptors compete with wild-type receptors at TREs or compete for auxiliary transcription factors $(13,14,18)$. The mutations of $\beta$-receptor found in GRTH avoid the important heptad repeats of the $T_{3}$-binding domain that are thought to be required for receptor-protein interactions (34). Furthermore, these mutations are separated from the TRAP domain, also necessary for such interactions (36-44). Therefore, the GRTH mutants can, theoretically, successfully compete with wild-type receptors for TREs and inhibit thyroid hormone action. Identification of the G.H. receptor strongly supports a model for receptor-protein interactions in mediating thyroid hormone action in vivo. If no such interactions were important, the G.H. receptor with an intact DNA-binding domain would have been expected to behave as a potent dominant negative protein, resulting in thyroid hormone resistance in the father and half-sister of patient G.H. We speculate that the ARG-311-HIS mutation perturbs a dimerization or TRAP domain of the c-erbA $\beta$ receptor, abrogating its ability to compete with wild-type receptor for transcription factors or to form a transcription complex with high affinity for TREs. The crucial structural role of codon 311 in c-erbA $\beta$ must await crystallographic data, which will resolve the putative dimerization and TRAP domains. However, the special role of codon 311 in c-erbA $\beta$ structure and function is further suggested by the complete conservation of arginine at this site in the retinoic acid and vitamin $\mathrm{D}$ receptors, c-erbA, v-erbA and Rev-erbA (34). A GRTH mutation at codon 312 reported by Parrilla et al. (9) more modestly affected $T_{3}$-binding affinity compared with G.H., and this codon is not so strictly conserved among other members of the thyroid/steroid gene superfamily. Future investigations using cloned retinoid $X$ receptors and other possible TRAP factors with assorted TREs in gelshift and transfection assays will be necessary to characterize the range of effects the G.H. mutation has on DNA-binding affinities, heterodimerization, transactivation, and dominant negative function.

A trivial explanation for the lack of dominant negative activity from the G.H. allele would be that the G.H. receptor protein is not produced. This seems extremely unlikely, given that the G.H. receptor synthesized in reticulocyte lysate was quite stable and could be purified after bacterial expression (Samuels, H. H., and F. Su, New York University Medical 
Center, unpublished data). Furthermore, Meier et al. (13) have demonstrated that a wide range of GRTH receptors are stable in transfected HeLa cells.

Another important conclusion of this study is that it suggests possible molecular heterogeneity to thyroid hormone resistance syndromes. GRTH has been shown to be a genetically homogeneous syndrome. However, the form of PRTH that patient G.H. has cannot be due to the single mutant G.H. allele. One can speculate that the severe pituitary resistance of patient G.H. may be due to a second mutation in the remaining c-erbA $\beta$ allele or c-erbA $\alpha$ alleles of the thyrotrophs, resulting in a dominant negative mutant, combined with compromised thyroid hormone responsiveness due to a null c-erbA $\beta$ allele. Although this second putative mutation is predicted to be somatic, we have sequenced multiple clones of the last two exons of c-erbA $\alpha$ from patient G.H. that correspond to $\beta$-exons 9 and 10, and no mutation was found (data not shown). Furthermore, we have considered the possibility of a germ-line mutation in the promoter of $\mathrm{hTSH} \beta$ (49) and have found no mutation in the +3- to +37-bp segment of this promoter. It is also possible that the putative second somatic mutation may not result in a dominant negative thyroid hormone receptor but may be in a retinoid $X$ receptor gene or a yet to be identified TRAP gene.

Finally, it must be recognized that patient G.H. is unique in her serum levels of thyroid hormones; many other patients diagnosed with PRTH have total thyroxine levels $<20-25 \mu \mathrm{g} /$ $\mathrm{dl}(25,50)$. Although the clinical condition of PRTH may turn out to be heterogeneous in terms of molecular etiology, $c-\operatorname{erbA} \beta$ defects may be generally involved with different clinical forms of this syndrome. We have found a LEU-325-PHE mutation in a previously published patient with PRTH (24, 51). The original patient with PRTH described by Gershengorn and Weintraub (23) has recently been found to have a common c-erbA $\beta$ mutation (52). Further clinical and genetic studies will be necessary to explain the molecular basis of the variable clinical forms of PRTH.

\section{Acknowledgments}

We thank Dr. Fredric Wondisford, Case Western Reserve University, Cleveland, $\mathrm{OH}$, for assistance with the hTSH $\beta$ gene. We thank Allen E. Bale, Department of Human Genetics, Yale University, New Haven, CT, for useful discussions. We thank the East Carolina University Text Information Processing Center for typing the manuscript. We are appreciative of special assistance from Endocrine Sciences (Calabasas Hills, CA).

Stephen J. Usala was supported by Department of Health and Human Services (DHHS) grant DK42807 and grant JFRA-351 from the American Cancer Society. Jerome M. Hershman was supported by Veterans' Administration Medical Research Funds. Nathan S. Ross was supported by DHHS grant HD25299. Herbert H. Samuels was supported by DHHS grant DK16636 and by the Hascle Foundation. Fei Su was supported by the Sackler Institute of Graduate Biomedical Sciences at New York University Medical Center.

\section{References}

1. Refetoff, S. 1982. Syndromes of thyroid hormone resistance. Am. J. Physiol. 243:E88-E98.

2. Usala, S. J. and B. D. Weintraub. 1991. Thyroid hormone resistance syndromes. Trends Endocrinol. Metab. 2:140-144.

3. Usala, S. J. 1991. Molecular diagnosis and characterization of thyroid hormone resistance syndromes. Thyroid. 1:361-367.
4. Sakurai, A., K. Takeda, K. Ain, P. Ceccarelli, A. Nakai, S. Seino, G. I. Bell, S. Refetoff, and L. J. DeGroot. 1989. Generalized resistance to thyroid hormone associated with a mutation in the ligand-binding domain of the human thyroid hormone receptor $\beta$. Proc. Natl. Acad. Sci. USA. 86:8977-8981.

5. Usala, S. J., G. E. Tennyson, A. E. Bale, R. W. Lash, N. Gesundheit, F. E. Wondisford, D. Accili, P. Hauser, and B. D. Weintraub. 1990. A base mutation of the $c-e r b \mathrm{~A} \beta$ thyroid hormone receptor in a kindred with generalized thyroid hormone resistance. J. Clin. Invest. 85:93-100.

6. Usala, S. J., J. B. Menke, T. L. Watson, J. Berard, C. Bradley, A. E. Bale, R. W. Lash, P. Hauser, and B. D. Weintraub. 1991. A novel point mutation in the $\mathrm{T}_{3}$-binding domain of the $\mathrm{c}-\operatorname{erbA} \beta$ is tightly linked to generalized thyroid hormone resistance. J. Clin. Endocrinol. Metab. 72:32-38.

7. Usala, S. J., J. B. Menke, T. L. Watson, F. E. Wondisford, B. D. Weintraub, J. Berard, W. E. C. Bradley, S. Ono, O. T. Mueller, and B. B. Bercu. 1991. A homozygous deletion in the $c-\operatorname{erb} \beta$ thyroid hormone receptor gene in a patient with generalized thyroid hormone resistance: isolation and characterization of the mutant receptor. Mol. Endocrinol. 5:327-335.

8. Cugini, C. D., Jr., J. W. Leidy, Jr., B. S. Chertow, J. Berard, W. E. C. Bradley, J. B. Menke, E. H. Hao, and S. J. Usala. 1992. An arginine to histidine mutation in codon 315 of the c-erbA $\beta$ thyroid hormone receptor in a kindred with generalized resistance to thyroid hormones results in a receptor with significant 3,5,3'-triiodothyronine binding activity. J. Clin. Endocrinol. Metab. 74:1164-1170.

9. Parrilla, R., A. J. Mixson, J. A. McPherson, J. H. McClaskey, and B. D. Weintraub. 1991. Characterization of seven novel mutations of the $c-e r b A \beta$ gene in unrelated kindreds with generalized thyroid hormone resistance: evidence for two "hot spot" regions of the ligand-binding domain. J. Clin. Invest. 88:21232130 .

10. Takeda, K., R. E. Weiss, and S. Refetoff. 1992. Rapid location of mutations in the thyroid hormone receptor $\beta$ gene by denaturing gradient electrophoresis in eighteen families with thyroid hormone resistance. J. Clin. Endocrinol. Metab. 74:712-719.

11. Burman, K. D., Y. Y. Djuh, D. Nicholson, H. Fein, S. Usala, W. E. C. Bradley, J. Berard, and L. Wartofsky. 1991. Identification of a unique mutation in affected members of a family with the syndrome of generalized thyroid hormone resistance. Prog. Abstr. 73rd Annu. Meet. Endocr. Soc. p. 242.

12. Mixson, A. J., R. Parrilla, S. C. Ransom, E. A. Wiggs, J. H. McClaskey, P. Hauser, and B. D. Weintraub. 1992. Correlations of language abnormalities with localization of mutations in the $\beta$-thyroid hormone receptor in 13 kindreds with generalized resistance to thyroid hormone: identification of four novel mutations. J. Clin. Endocrinol. Metab. 75:1039-1045.

13. Meier, C. A., B. M. Dickstein, K. Ashizawa, J. H. McClaskey, P. Muchmore, S. C. Ransom, J. B. Menke, E. H. Hao, S. J. Usala, B. B. Bercu, et al. 1992. Variable transcriptional activity and ligand binding of mutant $\beta 1 T_{3}$ receptors from four families with generalized resistance to thyroid hormone. Mol. Endocrinol. 6:248-258.

14. Chatterjee, V. K. K., T. Nagaya, L. D. Madison, S. Datta, A. Rentoumis, and J. L. Jameson. 1991. Thyroid hormone resistance syndrome. Inhibition of normal receptor function by mutant thyroid hormone receptors. J. Clin. Invest. 87:1977-1984.

15. Sap, J., A. Munoz, K. Damm, Y. Goldberg, J. Ghysdael, A. Levtz, J. Beng, and B. Vennstrom. 1986. The c-erbA $\alpha$ protein is a high-affinity receptor for thyroid hormone. Nature (Lond.). 324:635-640.

16. Refetoff, S., L. T. DeWind, and L. J. DeGroot. 1967. Familial syndrome combining deaf mutism, stippled epiphyses, goiter, and abnormally high PBI: possible target organ refractoriness to thyroid hormone. J. Clin. Endocrinol. Metab. 27:279-294.

17. Refetoff, S., L. J. DeGroot, B. Bernard, and L. T. DeWind. 1972. Studies of a sibship with apparent hereditary resistance to the intracellular action of thyroid hormone. Metabolism. 21:723-756.

18. Takeda, K., S. Balzano, A. Sakurai, L. J. DeGroot, and S. Refetoff. 1991. Screening of nineteen unrelated families with generalized resistance to thyroid hormone for known point mutations in the thyroid hormone receptor $\beta$ gene and the detection of a new mutation. J. Clin. Invest. 87:496-502.

19. Takeda, K., A. Sakurai, L. J. DeGroot, and S. Refetoff. 1992. Recessive inheritance of thyroid hormone resistance caused by complete deletion of the protein coding region of the thyroid hormone receptor $\beta$ gene. J. Clin. Endocrinol. Metab. 74:49-55.

20. Usala, S. J., B. B. Bercu, and S. Refetoff. Diverse abnormalities of the c-erbA $\beta$ thyroid hormone receptor gene in generalized thyroid hormone resistance. 1991. In Advances in Perinatal Thyroidology. B. B. Bercu and D. I. Shulman, editors. Plenum Press, New York. 251-258.

21. Ono, S., I. D. Schwartz, O. T. Mueller, A. W. Root, S. J. Usala, and B. B. Bercu. 1991. Homozygosity for a dominant negative thyroid hormone receptor gene responsible for generalized thyroid hormone resistance. J. Clin. Endocrinol. Metab. 73:990-994.

22. Sakurai, A., T. Miyamoto, S. Refetoff, and L. DeGroot. 1990. Dominant negative transcriptional regulation by a mutant thyroid hormone receptor $-\beta$ in a 
family with generalized resistance to thyroid hormone. Mol. Endocrinol. 4:19881994.

23. Gershengorn, M. C., and B. D. Weintraub. 1975. Thyrotropin-induced hyperthyroidism caused by selective pituitary resistance to thyroid hormone: a new syndrome of "inappropriate secretion of TSH." J. Clin. Invest. 56:633-643.

24. Dulgeroff, A. J., M. E. Geffner, S. N. Koyal, M. Wong, and J. M. Hershman. 1992. Bromocriptine and triac therapy for hyperthyroidism due to pituitary resistance to thyroid hormone. J. Clin. Endocrinol. Metab. 75:1071-1075.

25. Kunitake, J. M., N. Hartman, L. C. Henson, J. Lieberman, D. E. Williams, M. Wong, and J. M. Hershman. 1989. 3,5,3'-triiodothyroacetic acid therapy for thyroid hormone resistance. J. Clin. Endocrinol. Metab. 69:461-466.

26. Wynne, A. G., H. Gharib, B. W. Scheithauer, D. H. Davis, and S. L. Freeman. 1992. Hyperthyroidism due to inappropriate secretion of thyrotropin in 10 patients. Am. J. Med. 92:15-24.

27. Usala, S. J., A. E. Bale, N. Gesundheit, C. Weinberger, R. W. Lash, F. E. Wondisford, O. W. McBride, and B. D. Weintraub. 1988. Tight linkage between the syndrome of generalized thyroid hormone resistance and the human c-erbA $\beta$ gene. Mol. Endocrinol. 2:1217-1220.

28. Usala, S. J., and B. D. Weintraub. 1991. Familial thyroid hormone resistance: clinical and molecular studies. In Advances in Endocrinology and Metabolism. Mosby Year Book, Chicago. 59-72.

29. Sakurai, A., A. Nakai, and L. J. DeGroot. 1990. Structural analysis of human thyroid hormone receptor $\beta$ gene. Mol. Cell. Endocrinol. 71:83-91.

30. Weinberger, C., C. C. Thompson, E. S. Ong, R. Lebo, D. J. Gruol, and R. M. Evans. 1986. The c-erbA $\beta$ gene encodes a thyroid hormone receptor. Nature (Lond.). 324:641-646.

31. Forman, B. M., J. Casanova, B. M. Raaka, J. Ghysdael, and H. H. Samuels. 1992. Half-site spacing and orientation determine whether thyroid hormone and retinoic acid receptors and related factors bind to DNA response elements as monomers, homodimers, or heterodimers. Mol. Endocrinol. 6:429-442.

32. Umesono, K., V. Giguere, C. K. Glass, M. G. Rosenfeld, and R. M. Evans. 1988. Retinoic acid and thyroid hormone induce gene expression through a common responsive element. Nature (Lond.). 336:262-265.

33. Forman, B. M., and H. H. Samuels. 1991. pEXPRESS: a family of expression vector containing a single transcription unit active in prokaryotes, eukaryotes and in vitro. Gene (Amst.). 105:9-15.

34. Forman, B. M., C. Yang, M. Au, J. Casanova, J. Ghysdael, and H. H. Samuels. 1989. A domain containing a leucine-zipper like motif mediates nove in vitro interactions between the thyroid hormone and retinoic acid receptors. Mol. Endocrinol. 3:1610-1626.

35. Behr, M., and U. Loos. 1992. A point mutation Ala229 to Thr in the hinge domain of the c-erbA $\beta$ thyroid hormone receptor gene in a family with generalized thyroid hormone resistance. Mol. Endocrinol. 6:1119-1126.

36. Murray, M. B., and H. C. Towle. 1989. Identification of nuclear factors that enhance binding of the thyroid hormone receptor to a thyroid hormone response element. Mol. Endocrinol. 3:1434-1442.

37. Burnside, J., D. S. Darling, and W. W. Chin. 1990. A nuclear factor that enhances thyroid hormone receptors to thyroid hormone response elements. $J$. Biol. Chem. 265:2500-2504.

38. O'Donnell, A. L., and R. J. Koenig. 1990. Mutational analysis identifies a new functional domain of the thyroid hormone receptor. Mol. Endocrinol. 4:715-720.
39. Lazar, M. A., and T. J. Berrodin. 1990. Thyroid hormone receptors form distinct nuclear protein-dependent and independent complexes with a thyroid hormone response element. Mol. Endocrinol. 4:1627-1635.

40. O'Donnell, A. L., E. V. Rosen, D. S. Darling, and R. J. Koenig. 1991 Thyroid hormone receptor mutations that interfere with transcriptional activation also interfere with receptor interaction with a nuclear protein. Mol. Endocrinol. 5:94-99.

41. Darling, D. S., J. S. Beebe, J. Burnside, E. R. Winslow, and W. W. Chin 1991. 3,5,3'-Triiodothyronine $\left(T_{3}\right)$ receptor-auxiliary protein (TRAP) binds DNA and forms heterodimers with the $\mathrm{T}_{3}$ receptor. Mol. Endocrinol. 5:73-84.

42. Yen, P. M., D. S. Darling, and W. W. Chin. 1991. Basal and thyroid hormone receptor auxiliary protein-enhanced binding of thyroid hormone receptor isoforms to native thyroid response elements. Endocrinology. 129:3331-3336.

43. Spanjaard, R. A., D. S. Darling, and W. W. Chin. 1991. Ligand-binding and heterodimerization activities of a conserved region in the ligand-binding domain of the thyroid hormone receptor. Proc. Natl. Acad. Sci. USA. 88:85878591.

44. Lazar, M. A., T. J. Berrodin, and H. P. Harding. 1991. Differential DNA binding by monomeric, homodimeric, and potentially heterodimeric forms of the thyroid hormone receptor. Mol. Cell. Biol. 11:5005-5015.

45. Leid, M., P. Kastner, R. Lyons, H. Nakshatri, M. Saunders, T. Zacharewski, J. Y. Chen, A. Staub, J. M. Garnier, S. Mader, and P. Chambon. 1992. Purification, cloning, and RXR identity of the Hela cell factor with which RAR or TR heterodimerizes to bind target sequences efficiently. Cell. 68:377-395.

46. Yu, V. C., C. Delsert, B. Andersen, J. M. Holloway, O. V. Devary, A. M. Naar, S. Y. Kim, J. M. Boutin, C. K. Glass, and M. G. Rosenfeld. 1991. RXR $\beta$ : a coregulator that enhances binding of retinoic acid, thyroid hormone, and vitamin D receptors to cognate response elements. Cell. 67:1251-1266.

47. Zhang, S. K., B. Hoffmann, P. B. V. Tran, G. Graupner, and M. Pfahl 1992. Retinoid X receptor is an auxiliary protein for thyroid hormone and retinoic acid receptors. Nature (Lond.). 355:441-445.

48. Kliewer, S. A., K. Umesono, D. J. Mangelsdorf, and R. M. Evans. 1992 Retinoid X interacts with nuclear receptors in retinoic acid, thyroid hormone and vitamin D signalling. Nature (Lond.). 355:446-449.

49. Wondisford, F. E., E. A. Farr, S. Radovick, J. H. Steinfelder, J. Moates, J. H. McClaskey, and B. D. Weintraub. 1990. Thyroid hormone inhibition of human thyrotropin $\beta$-subunit gene expression is mediated by a cis-acting element located in the first exon. J. Biol. Chem. 264:14601-14604.

50. Beck-Peccoz, P., S. Mariotti, P. J. Guillausseau, G. Medri, G. Piscitelli, A Bertoli, A. Barbarino, M. Rondena, P. Chanson, A. Pinchera, and G. Faglia. 1989. Treatment of hyperthyroidism due to inappropriate secretion of thyrotropin with the somatostatin analog SMS 201-995. J. Clin. Endocrinol. Metab. 68:208-214.

51. Usala, S. J., J. B. Menke, E. H. Hao, D. Thomas, M. Liu, N. Ross, M. E. Geffner, and J. M. Hershman. 1992. Mutations in the c-erbA-beta gene in two different patients with selective pituitary resistance to thyroid hormones. Prog. Abstr. 74th Annu. Meet. Endocr. Soc. p. 135.

52. Mixson, A. J., J. C. Renault, S. Ransom, D. L. Bodenner, and B. D. Weintraub, 1993. Identification of a novel mutation in the gene encoding the $\beta$-triiodothyronine receptor in a patient with apparent selective pituitary resistance to thyroid hormone. Clin. Endocrinol. In press. 